\title{
Pengembangan Modul E-Learning Berbasis LMS Sebagai Media Interaktif Pada Pelajaran Simulasi Dan Komukasi Digital
}

\author{
Wirda Yetti ${ }^{1 *}$, Ahyanuardi ${ }^{2}$ \\ ${ }^{1}$ Program Studi Pendidikan Teknologi dan Kejuruan, Fakultas Teknik, Universitas Negeri Padang \\ ${ }^{2}$ Jurusan Teknik Elektro, Fakultas Teknik, Universitas Negeri Padang \\ "Corresponding author, e-mail: yeti.wirda78@gmail.com
}

\begin{abstract}
Abstrak- Penggunaan media yang tepat dapat menjadi salah satu solusi dalam melengkapi strategi pembelajaran yang tepat, salah satu media yang cocok dalam era digitalisasi saat ini adalah modul e-learning, modul E-learning yang merupakan sumber belajar yang kekinian sesuai dengan perkembangan teknologi. Oleh karena itu, tujuan dari penelitian adalah untuk mengembangkan modul e-learning berbasis LMS sebagai media interaktif pada mata pelajaran simulasi dan komunikasi digital. Model pengembangan yang digunakan adalah pengembangan model 4-D (Four D Models), yang terdiri dari define, design, development dan disseminate. Sampel penelitian ini adalah 3 orang validator desain dan 3 orang validator materi. Sedangkan uji praktikalitas yaitu 3 orang guru dan 30 orang siswa SMKN 1 Lubuksikaping pada mata diklat Simulasi dan Komunikasi Digital Kelas X DPIB dan Untuk uji validitas dan praktikalitas menggunakan angket. Berdasarkan hasil penelitian didapatkan bahwa uji modul e-learning terbukti valid dan praktis untuk digunakan pada pembelajaran simulasi dan komunikasi digital, sehingga dapat. Disimpulkan bahwa modul e-learning ini dapat digunakan sebagai media pembelajaran pada pembelajaran simulasi dan komunikasi digital.
\end{abstract}

Kata Kunci : Modul E-learning, Learning Management System, Four-Ds (4Ds)

\begin{abstract}
The use of the right media can be one of the solutions in completing the right learning strategy, one of the suitable media in the current era of digitalization is the elearning module, the E-learning module which is a source of learning that is up to date in accordance with technological developments. This study aims at developing an LMS-based e-learning module as an interactive media in simulation and digital communication subjects. The development model used is the development of the 4-D model (Four D Models), which consists of define, design, development and disseminate. The sample of this research is 3 experts of designs validator and 3 experts of materials validator. While the practicality test was 3 teachers and 30 students of SMKN 1 Lubuksikaping in the grade $X$ of DPIB on Simulation and Digital Communication training subject and to test the validity and practicality using a questionnaire. Based on the results of the study, it was found that the elearning module was valid and practical for use in simulation learning and digital communication, so it was reliable. Dis that this e-learning module can be used as a learning medium in simulation learning and digital communication.
\end{abstract}

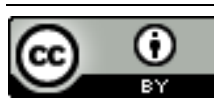

This is an open access article distributed under the Creative Commons 4.0 Attribution License

\section{Pendahuluan}

Pendidikan dimasa Revolusi Industri 4.0 tertantang untuk mempersiapkan diri masuk ke babak baru yang siap menghadapi perubahan dan perkembangan teknologi. Revolution Industry (RI) 4.0 mencakup sistem Smart Technology IoT (Internet of Things), Artificial Intellegence, Human Machine Interface, Teknologi Robotik dan Sensor, yang merupakan trending dalam dunia industri yang mengkolaborasikan teknologi otomatisasi dan cyber [1]. Tantangan tersebut mencakup pada kesiapan dunia industri, adanya tenaga kerja yang terpercaya yang dicetak oleh SMK, dan terciptanya lapangan kerja dan peluang industri. Tantangan dan peluang masa revolusi indusri 4.0 mendorong inovasi dan kreasi dalam pendidikan vokasi atau pendidikan kejuruan dengan berorientasi pada kinerja individu dalam dunia industry [2], 
keterampilan yang diberikan sesuai dengan kebutuhan di lapangan, fokus kurikulum pada aspek psikomotorik, afektif dan kognitif, tolak ukur keberhasilan tidak hanya terbatas di sekolah, namun harus peka terhadap perkembangan di dunia kerja, adanya sarana dan prasarana yang memadai serta adanya dukungan dari berbagai pihak demi terciptanya tujuan Pendidikan [3].

Para pendidik harus mampu mengiringi perkembangan IPTEK dan tanggap dalam menggunakan teknologi tersebut dalam proses pembelajaran. Jika dulunya dalam mengajar menggunakan media gambar nyata yang dibuat manual oleh guru dan di tempel di depan kelas, sekarang tinggal cari melalui Internet dan di tampilkan dengan menggunakan Infokus (LCD Proyektor) [4]. Didalam kelas guru membentuk kelompok belajar untuk berdiskusi memecahkan suatu masalah, dan bahkan waktu tidak cukup dengan tatap muka 3 x 45 menit perminggu, kemudian ada penugasan secara individu dan kelompok, dilanjutkan di luar jam tatap muka, dengan adanya perkembangan teknologi memberikan solusi bagaimana mengatur pembelajaran lebih efektif dan efisien dengan mengembangkan berbagai aplikasi dan memanfaatkan akses jaringan internet. Dalam dunia pendidikan sudah banyak aplikasi jejaring sosial yang khusus untuk pendidikan seperti Classroom, Moodlle, Edmodo, google hangouts, Video Converence dan juga aplikasi khusus untuk pembejaran yang sudah dikembangkan seperti rumah belajar, si cadiak pandai, ruang guru dan lain-lain. Guru sebagai pendidik tinggal memilih media pembelajaran yang tepat sesuai dengan kompetensi keahliannya masing-masing [5].

Modul adalah salah satu jenis media pembelajaran yang sangat penting dan bermanfaat dalam proses belajar mengajar. Dengan adanya modul maka siswa akan terbantu untuk mendapatkan informasi terkait materi yang sedang dipelajari karena modul dirancang sesuai dengan kebutuhan peserta didik, berbeda dengan buku cetak yang ada diperpustakaan sekolah, modul dapat dikembangkan oleh guru meyesuaikan perkembangan Ilmu Pengetahuan dan Teknologi. Sebagai contoh dalam mempelajari Microsoft office, dari tahun ke tahun perkembangan software ini begitu cepat tahun kemaren masih menggunakan Microsoft office 2007 sekarang sudah menggunakan Microsoft Office 2013 jika hanya mengandalkan buku cetak tentu materi menjadi tidak update [6].

Realita yang terjadi saat ini adalah sebagian besar efektifitas dan kualitas pembelajaran masih monoton dan tidak update dengan perkembangan teknologi, ditambah lagi dengan beban tugas guru selain melaksanakan pengelolaan kelas juga dituntut harus memiliki Sertifikat Kompetensi, mengikuti Pendidikan dan Pelatihan, membuat Karya Ilmiah, karya Inovatif atau Penelitian Tindakan Kelas yang merupakan syarat untuk bisa naik pangkat, yang pada akhirnya interaksi guru dan peserta didik tidak dapat dilakukan, ditambah libur nasional yang semuanya berdampak jumlah tatap muka tidak sesuai dengan program semester atau program tahunan yang telah di rancang oleh guru pada awal semester. Sejumlah upaya telah dilakukan melalui penelitian dengan menerapkan stategi pembelajaran yang tepat untuk mengatasi permasalahan yang terjadi, dampaknya cukup signifikan namun belum mampu memfasilitasi siswa untuk memiliki kemampuan sesuai dengan kebutuhan pada masa R.I 4.0 saat ini. Seperti penerapan media interaktif, dimana kekurangannya hanya media offline saja, dan tidak bisa diakes secara online [7], media mobile learning yang hanya terpaku pada penilaian sumatif saja [8], CD interaktif, dimana siswa harus membuka aplikasi dengan menggunakan $\mathrm{CD}$, hal itu membuat pembelajaran menjadi tidak praktis [9]. Padahal kompetensi yang harus dimiliki adalah prilaku yang inovatif, kritis, spritual, pengetahuan digitalisasi dan komputerisasi, memiliki keterampilan dan skill serta berkolaborasi dengan teamwork [10].

Oleh karena itu, penggunaan media yang tepat dapat menjadi salah satu solusi dalam melengkapi strategi pembelajaran yang tepat, salah satu media yang cocok dalam era digitalisasi saat ini adalah modul e-learning, banyak penelitian yang telah dilakukan mengenai keefektifan penerapan modul e-learning di dalam pembelajaran, dan hasilnya menunjukkan bahwa modul e-learning memberikan efek yang positif terhadap pembelajaran, seperti pada mata pelajaran teknologi komunikasi [11], materi pedsofer [12] dan mata pelajaran KKPI [13].

Keunggulan dari modul e-learning berbasis LMS yang dikembangkan ini adalah sebagai alat bantu dalam proses belajar mengajar yang dapat merangsang pemikiran, perhatian, perasaan, kemampuan dan skill peserta didik hingga dapat mendorong terjadinya proses pembelajaran. Salah satu faktor yang sangat menentukan keberhasilan dalam pembelajaran adalah media, ibaratnya media adalah perantara antara penerima pesan dengan pengirim pesan

Materi pada modul e-learning berbasis LMS ini lebih mudah dipahami dan menggunakan bahasa guru bukan bahasa buku, kemudian modul 
dikembangkan dilengkapi dengan gambar yang menarik dalam menjelaskan langkah kerja dan memberikan contoh langsung pemakaian materi dalam kehidupan nyata, sesuai dengan perkembangan yang ada, dan juga modul $E$ learning yang merupakan sumber belajar yang kekinian sesuai dengan perkembangan teknologi informasi, agar pembelajaran bisa lebih menyenangkan dan mampu meningatkan motivasi belajar, pada akhirnya hasil berlajar juga meningkat [6][14].

Kelebihan penggunan modul e-learning berbasis LMS ini untuk pembelajaran adalah menumbuhkan motivasi bagi peserta didik karena bahasa pada modul lebih mudah dipahami dan dan materi sesuai dengan tuntutan silabus, berurut berdasarkan Kompetensi Dasar yang ingin di capai (sequencing) dan modul dirancang mengacu kepada upaya guru menyajikan materi sesuai dengan fakta di lapangan, konsep dan prosedur pembelajaran serta menjelaskan prinsip yang terkandung pada materi dalam proses belajar mengajar (synthesizing). Perancangan materi ajar harus memiliki lima kategori kapabilitas yang bisa diberikan kepada peserta didik yaitu informasi bersifat verbal, memperhatikan keterampilan intelektual, sikap peserta didik, bagaimana strategi kognitif atau pengetahuan peserta didik dan bagaimana keterampilan motorik dari peserta didik tersebut [6].

Sistem pembelajaran dengan menggunakan modul ini sudah dikembangkan secara nasional ataupun internasional yang dikenal dengan Sistem Belajar Bermodul yang di singkat dengan SBB, dengan model pengembangan yang bervariasi sesuai dengan perencanaan kegiatan pembelajaran oleh guru namun tidak terlepas dari tuntutan silabus. Tujuan pokok dari pengembangan modul adalah untuk efektif dan efisien serta layak digunakan, artinya dengan adanya modul pembelajaran lebih mudah dipahami dalam mencapai kompetensi tertentu dan menyenangkan, hemat waktu dan biaya serta dapat digunakan kapan dan dimana saja, tidak hanya saat tatap muka dalam jadwal pembelajaran di sekolah. Kemudian layak digunakan ini ditentukan oleh sistematika penulisan modul, materi yang relevan dengan kompetensi terukur serta menggunakan rujukan yang kekinian atau mutakhir [14].

Bertepatan pula dengan adanya pendemi covid19, yang membawa perubahan terhadap proses pembelajaran, pembelajaran dilakukan di rumah secara Daring, pengembangan ini mampu menjawab permasalahan terhadap efektifitas pembelajaran secara daring dengan aplikasi khusus. Hasil penelitian pengembangan e-modul interaktif berbasis proyek juga telah dilakukan sebelumnya menunjukkan bahwa hasil penelitian tentang pengembangan rancangan e-modul interaktif yang diterapkan pada mata pelajaran Simulasi dan Komunikasi Digital berhasil dan layak diimplementasikan dalam proses belajar mengajar [15]. Oleh karena penelitian ini bertujuan untuk mengembangkan modul e-learning berbasis LMS sebagai media interaktif yang valid dan efektif untuk diterapkan pada mata pelajaran Simulasi dan Komunikasi Digital.

\section{MetodA}

\section{A. Metode Pengembangan}

Model pengembangan yang digunakan adalah pengembangan model 4-D (Four D Models) yang dikembangkan oleh Thiagarajan [16]. Model pengembangan 4-D terdiri atas 4 tahap utama yaitu: Define (Pendefinisian), Design (Perancangan), Develop (Pengembangan) dan Disseminate (Penyebaran). Artikel ini berfokus pada tahap desain dan pengembangan, yaitu tentang pengembangan system, menguji valditas dan praktikalitas.

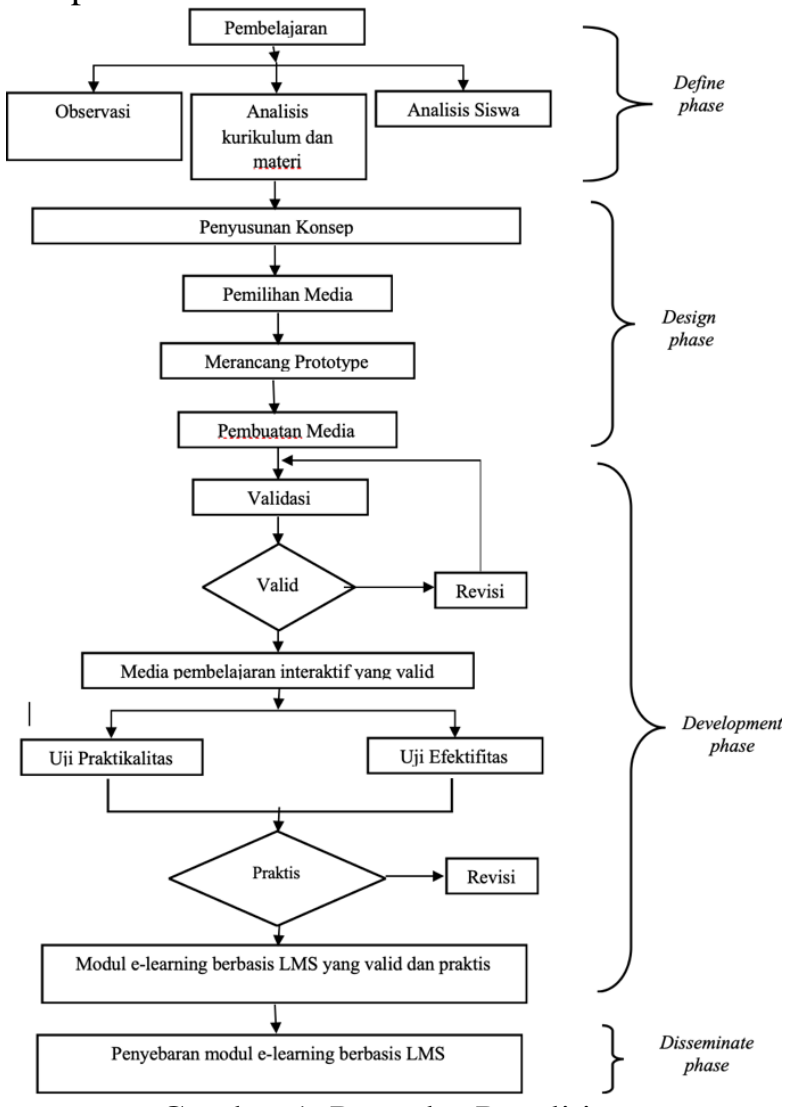

Gambar 1. Prosedur Penelitian

Pada modul e-learning ini terdapat informasi atau pemberitahuan oleh guru, komunikasi antara guru dengan peserta didik dan antar peserta didik 
dalam satu kelas, materi, penugasan, latihan dan ujian. Produk E-learning dapat digunakan saat tatap muka dan juga secara online, sehingga diharapkan pembeajaran lebih efektif dan efisien.

\section{B. Sampel Penelitian}

Uji validitas dilakukan kepada 3 orang validator desain dan 3 orang validator materi. Sedangkan uji praktikalitas yaitu 3 orang guru dan 30 orang siswa SMKN 1 Lubuksikaping pada mata diklat Simulasi dan Komunikasi Digital Kelas XDPIB. Subjek ini di pilih dengan pertimbangan bahwa lingkungan sekolah mendukung terlaksananya penelitian, lokasi tempat kerja peneliti sendiri, mudah di jangkau dan keterbukaan semua pihak sekolah dalam menerima inovasi baru.

\section{Instrumen Penelitian}

Untuk uji validitas dan praktikalitas menggunakan angket, untuk uji validitas terdiri dari validitas media dan desain, sedangkan uji praktikalitas terdiri dari uji praktikalitas guru dan siswa.

\section{HASIL DAN PEMBAHASAN}

Pada penelitian ini dihasilkan modul elearning berbasis LMS sebagai media interaktif pada pembelajaran Simulasi dan Komunikasi Digital yang valid dan praktis. Modul e-learning berbasis LMS ini dikembangkan berdasarkan kebutuhan siswa, sekolah dan pembelajaran Simulasi dan Komunikasi Digital. Setelah modul e-learning ini dikembangkan, maka dilakukan pengujian pada para ahli untuk melihat apakah modul e-learning ini layak untuk diujicobakan dan diterapkan didalam pembelajaran. Jika telah valid, maka modul ini akan diterapkan dalam pembelajaran untuk melihat apakah model e-learning ini praktis atau tidak digunakan pada pembelajaran secara berkelanjutan. Berikut ini adalah tampilan dari modul berbasis LMS yang dikembangkan:

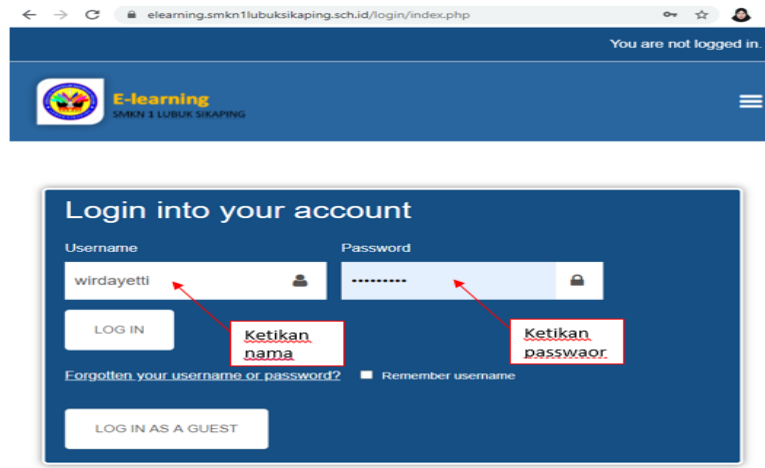

Gambar 1. Halaman Login
Gambar 1 diatas merupakan halaman login dari modul berbasis LMS yang dikembangkan, pada halaman ini terdapat username dan password yang harus diisi oleh siswa dan guru untuk dapat mengakses modul.

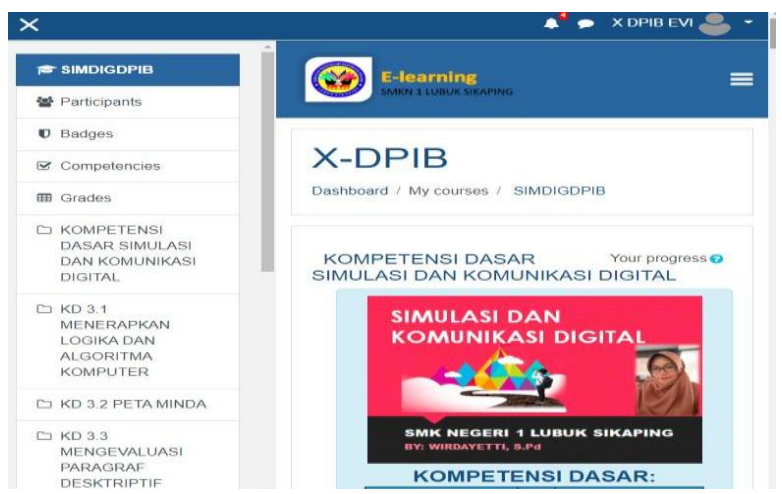

Gambar 2. Halaman Mata Pelajaran

Gambar 2 menampilkan halaman mata pelajaran Simulasi dan Komunikasi Digital, dimana pada halaman ini siswa dapat melihat $\mathrm{KI} / \mathrm{KD}$, tujuan dan materi pembelajaran.
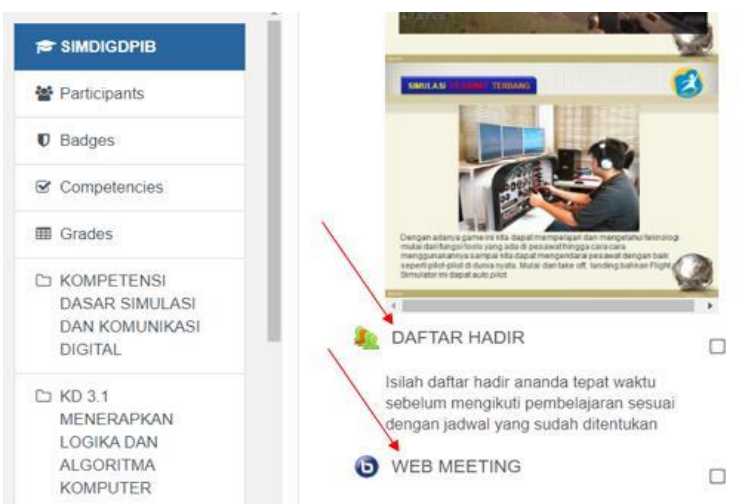

Gambar 3. Halaman Daftar Hadir dan Meeting

Siswa dapat mengisi daftar hadir pada halaman ditampilkan pada Gambar 3 diatas, guru dan siswa juga dapat melakukan video conference melalui web meeting.

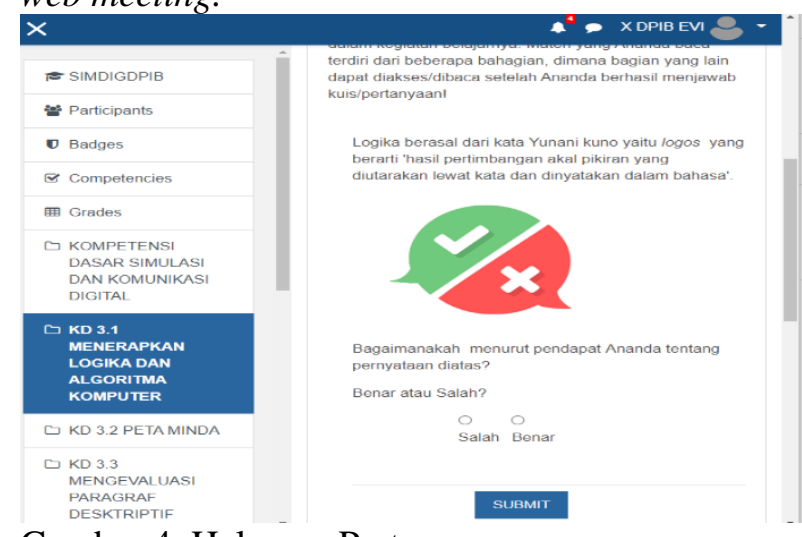

Gambar 4. Halaman Pertanyaan 
Gambar 4 menampilkan halaman pertanyaan, pertanyaan ini berfungsi untuk mengukur tingkat pemahaman siswa.

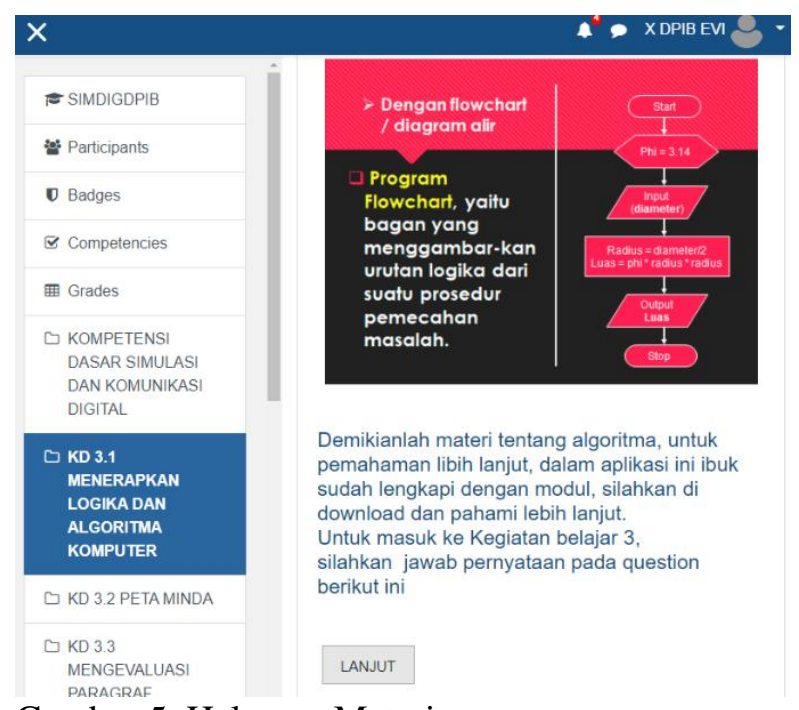

Gambar 5. Halaman Materi

Gambar 5 diatas menampilkan halaman materi tentang pembelajaran Simulasi dan Komunikasi Digital.

\section{X-DPIB}

Dashboard / My courses / SIMDIGDPIB / KD 31 MENERAPKAN LOGIKA DAN ALGORITMA KOMPUTER
/ MODUL LOGIKA DANALGORITMA KOMPUTER

\section{MODUL LOGIKA DAN ALGORITMA KOMPUTER}

Modul inı merupakan sumber belajar yang sudah di rancang untuk satu Kompetensi Dasar dan sudah dilengkapi dengen

Click MODUL 1 pat link to view the file.

4 KEGIATAN BELANAR LOGIKA

Gmabar 6. Halaman Tampilan Video Pembelajaran

Gambar 6 menampilkan halaman dimana siswa dapat mengakses video pembelajaran dari halaman tersebut. Validasi modul berbasis LMS ini divalidasi oleh 4 orang penimbang ahli (expert judgement), yang terdiri dari 2 orang penimbang ahli untuk desain dan 2 orang penimbang ahli untuk materi. Pada validasi desain, aspek yang dinilai adalah aspek didaktik, konstruksi dan teknis, sedangkan pada validasi materi, aspek yang dinilai adalah kualitas isi, pembelajaran, interaksi dan tampilan. Berikut ini adalah hasil validasi desain modul berbasis LMS (lihat Tabel 1) dan validasi materi pada modul berbasis LMS (lihat Tabel 2).

Tabel 1. Validasi Desin Modul Berbasis LMS

\begin{tabular}{lllll}
\hline No & Aspek & $\sum \mathrm{s}$ & $\mathrm{v}$ & kategori \\
\hline
\end{tabular}

\begin{tabular}{ccccc}
\hline & Aspek & 7 & 0,875 & Valid \\
& Didaktik & 7 & & \\
2 & Aspek & & & \\
& Konstruksi & 6 & 0,75 & Valid \\
3 & $\begin{array}{c}\text { Aspek } \\
\text { Teknis }\end{array}$ & 8 & 1 & Valid \\
\hline
\end{tabular}

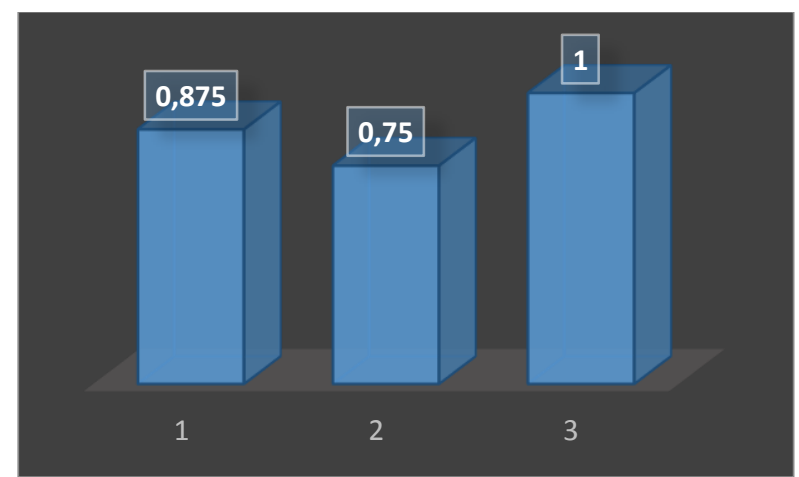

Gambar 6. Histogram Validasi Desain Modul Berbasis LMS

Pada Tabel 1 dan Gambar 6 diatas menunjukkan bahwa penilaian pada aspek didaktik yang diberikan oleh validator adalah valid $(\mathrm{V}=0,875)$, penilaian pada aspek konstruksi yang diberikan oleh validator juga valid $(\mathrm{V}=0,75)$ dan aspek Teknis juga memperoleh penilaian valid oleh validator $(\mathrm{V}=1)$, sehingga ketiga aspek tersebut termasuk dalam kategori valid.

Tabel 2. Validasi Materi Modul Berbasis LMS

\begin{tabular}{ccccc}
\hline No & Aspek & $\sum \mathrm{s}$ & $\mathrm{v}$ & kategori \\
\hline 1 & Kualitas Isi & 8 & 1 & Valid \\
2 & $\begin{array}{c}\text { Kualitas } \\
\text { Pembelajaran } \\
\text { Kualitas }\end{array}$ & 6 & 0,75 & Valid \\
3 & $\begin{array}{c}\text { Interaksi } \\
\text { Kualitas }\end{array}$ & 6 & 0,75 & Valid \\
4 & Tampilan & 7 & 0,875 & Valid \\
\hline
\end{tabular}

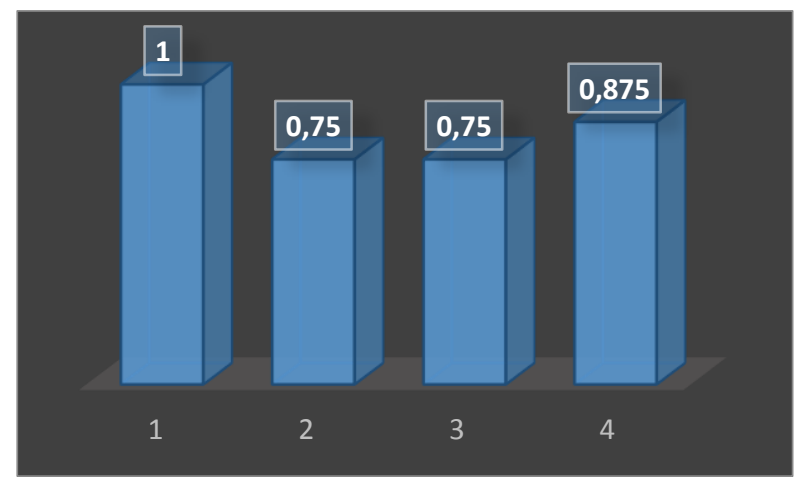

Gambar 7. Histogram Validasi Materi Modul Berbasis LMS 
Pada Tabel 2 dan Gambar 7 menunjukkan bahwa kualitas isi dari materi pada Modul berbasis LMS memperoleh penilaian yang valid $(\mathrm{V}=1)$, kualitas pembelajaran juga memperoleh penilaian yang valid $(\mathrm{V}=0,75)$, kualitas interaksi memperoleh penilaian yang valid $(\mathrm{V}=0,75)$ dan kualitas tampilan memperoleh penilaian yang sama yaitu valid $(\mathrm{V}=0,875)$, sehingga keempat aspek tersebut dapat dinyatakan valid. Jadi, berdasarkan hasil validasi desain modul dan materi pada modul berbasis LMS ini, menunjukkan bahwa modul berbasis LMS tersebut termasuk dalam kategori valid baik dari segi desain maupun materi.

Setelah modul berbasis LMS ini telah dinyatakan valid oleh penimbang ahli, maka dilakukanlah uji coba modul berbasis LMS tersebut untuk memperoleh data kepraktisan modul, uji coba modul berbasis LMS ini dilakukan selama 4 kali pertemuan, kepraktisan modul berbasis LMS ini ditinjau dari respon guru dan respon siswa. Berikut ini adalah hasil praktikalitas guru terhadap modul berbasis LMS (lihat Tabel 3) dan hasil praktikalitas siswa terhadap modul berbasis LMS (lihat Tabel 4).

Tabel 3. Hasil Praktikalitas/Respon Guru

\begin{tabular}{cccc}
\hline No & Aspek & $\begin{array}{c}\text { Persentase } \\
(\%)\end{array}$ & Kategori \\
\hline 1 & Kemudahan & 92 & $\begin{array}{l}\text { Sangat } \\
\text { Praktis }\end{array}$ \\
2 & $\begin{array}{c}\text { Efektifitas } \\
\text { Waktu }\end{array}$ & 86,7 & $\begin{array}{l}\text { Sangat } \\
\text { Praktis } \\
\text { Sangat } \\
\text { Praktis }\end{array}$ \\
\hline
\end{tabular}

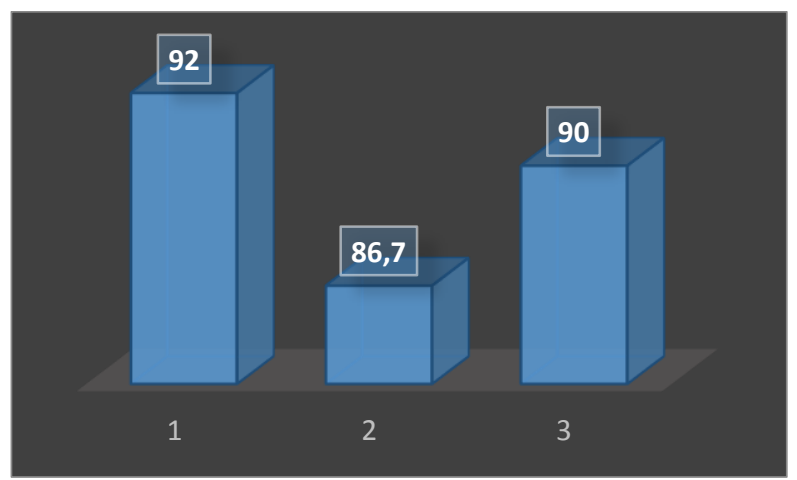

Gambar 8. Hasil Praktikalitas/Respon Guru

Pada Tabel 3 dan Gambar 8 menunjukkan bahwa respon guru terhadap penggunaan modul berbasis LMS, aspek kemudahan memperoleh kategori yang sangat praktis (persentase $=92 \%$ ), efektifitas juga memperoleh kategori yang sangat praktis (persentase $=86,7 \%$ dan penggunaan e- learning juga memperoleh kategori yang sangat praktis $($ persentase $=90 \%$ ), sehingga dapat disimpulkan bahwa respon guru terhadap penggunaan modul berbasis e-learning ini adalah sangat praktis.

Tabel 4. Hasil Praktikalitas/Respon Siswa

\begin{tabular}{|c|c|c|c|}
\hline No & Aspek & $\begin{array}{c}\text { Persentase } \\
(\%)\end{array}$ & Kategori \\
\hline 1 & Tampilan & 85,5 & $\begin{array}{l}\text { Sangat } \\
\text { Praktis }\end{array}$ \\
\hline 2 & $\begin{array}{l}\text { Penyajian } \\
\text { Materi }\end{array}$ & 84,8 & $\begin{array}{l}\text { Sangat } \\
\text { Praktis }\end{array}$ \\
\hline 3 & Manfaat & 85,8 & $\begin{array}{l}\text { Sangat } \\
\text { Praktis }\end{array}$ \\
\hline
\end{tabular}

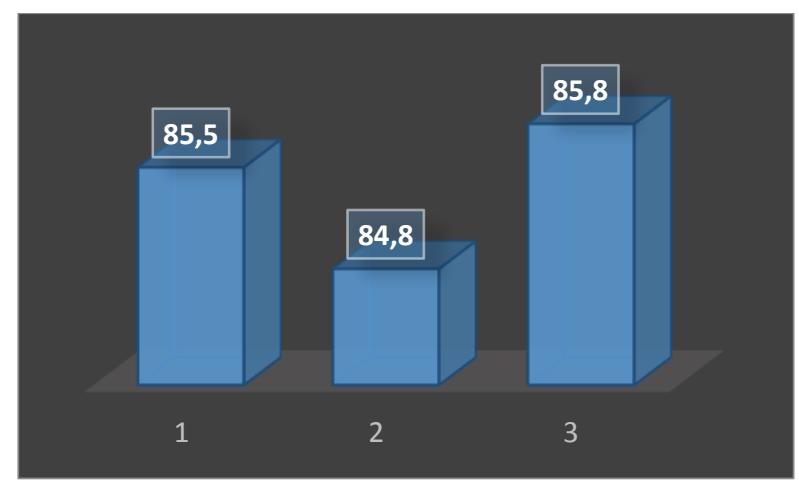

Gambar 9. Hasil Praktikalitas/Respon Siswa

Pada Tabel 4 dan Gambar 9 menunjukkan bahwa respon siswa terhadap modul berbasis LMS dari segi tampilan memperoleh kategori yang sangat praktis (persentase $=85,5 \%$ ), penyajian materi juga memperoleh kategori yang sangat praktis (persentase $=84,8 \%$ ) dan segi manfaat juga memperoleh kategori yang sangat praktis (persentase $=85,8 \%$ ), sehingga respon siswa terhadap modul berbasis LMS ini sangat praktis. Sehingga, berdasaarkan hasil praktikalitas guru dan siswa terhadap modul berbasis LMS, menunjukkan bahwa modul berbasis LMS ini dapat dilaksanakan oleh guru dan siswa, sehingga dapat disimpulkan bahwa modul berbasis LMS ini termasuk dalam kategori praktis.

Modul berbasis LMS sebagai media interaktif ini termasuk kategori valid, karena modul ini telah sesuai dengan format modul yang telah ditetapkan, yang berisi tentang kegiatan pembelajaran, materi, tes formatif, kesimpulan, daftar Pustaka dan feedback [17]. Hasil uji coba modul berbasis LMS ini juga termasuk dalam kategori praktis dalam meningkatkan hasil belajar siswa, hasil penelitian ini didukung oleh penelitian yang dilakukan oleh Wijaya \& Lubis [13] dan Dalu \& Rohman [13] bahwa penerapan modul dengan menggunakan 
LMS telah meningkatkan hasil belajar berupa aspek kognitif, afektif dan psikomotor.

Manfaat dari modul berbasis LMS untuk pembelajaran dapat membuat, mengelola, dan melaksanakan program pendidikan dan pelatihan serta menghemat jam kerja jika dibandingkan dengan metode tradisional. LMS memungkinkan pengorganisasian, tingkat otomatisasi dan pemrograman yang sesuai dengan kebutuhan pelajar [18]. Penggunaan ruang kelas online mengurangi biaya, dimana biaya paling banyak dalam bisnis adalah kesempatan siswa yang harus bepergian. Berkat LMS, institusi Pendidikan dapat menghemat biaya yang kemudian dapat mereka alokasikan ke sumber daya lain. Ruang kelas online memungkinkan pelatihan simultan bagi orangorang yang belajar dari lokasi geografis yang berbeda, dan kursus ini kemudian dapat digunakan berulang kali dengan kelompok pelajar baru [19].

Sistem ini juga memungkinkan institusi pendidikan untuk membuat konten pembelajaran multimedia yang komprehensif dan praktis, menggunakan video, gambar, audio dan teks yang semuanya berfungsi sebagai alat yang hebat dalam mempelajari keterampilan atau informasi baru. Siswa juga dapat berkomunikasi dengan guru dan teman sekelas mereka melalui platform obrolan dan forum online, menciptakan lingkungan belajar yang lebih kolaboratif, interaktif, menarik dan pribadi [20].

Serta semua informasi terstruktur secara terorganisir berada di tempat yang sama, sehingga dapat diakses oleh semua pengguna. Materi, kalender, konten multimedia, arsip dan evaluasi dapat diakses hanya dengan satu klik. Semua siswa memiliki akses ke konten dan materi pembelajaran kapan pun dan dimana pun di mana mereka memiliki akses internet [21]. LMS juga memfasilitasi komunikasi dan kolaborasi antar orang, baik itu siswa dan guru, atau antara semua pengguna platform dengan saluran komunikasi yang terbuka secara permanen. Mereka memfasilitasi manajemen komunikasi secara keseluruhan: email, pesan, forum, dan agenda global atau individu. Lingkungan tempat pengguna dapat menemukan semua informasi penting atau vital hanya dalam satu layer [22].

\section{KESIMPULAN}

Pada penelitian ini telah dihasilkan modul elearning berbasis LMS sebagai media interaktif yang valid dan praktis. Berdasarkan hasil penelitian, modul e-learning ini telah dinyatakan valid setelah divalidasi oleh 4 orang penimbang ahli baik dari segi desain maupun materi. Uji coba kepraktisan modul juga telah dilakukan melalui penerapan modul berbasis LMS pada pembelajaran Simulasi dan Komunikasi Digital, berdasarkan respon guru dan respon siswa, didapatkan bahwa modul berbasis LMS ini telah dinyatakan praktis. Implikasi dari penelitian ini adalah menambah referensi bagi dunia Pendidikan tentang penggunaan dan pemanfaatan media dalam proses pembelajaran. Dampak atau efektivitas dari modul berbasis LMS belum diteliti melalui penelitian ini, sehingga hal ini dapat dijadikan rekomendasi bagi peneliti yang lain untuk melakukan penelitian lebih lanjut, sehingga dapat menjadi pedoman dalam mengembangkan media pembelajaran pada materi dan konsep lain secara efektif.

\section{DAFTAR PUSTAKa}

[1] J. Lee, H. Kao, and S. Yang, "Service innovation and smart analytics for Industry 4 . 0 and big data environment," Procedia CIRP, vol. 16, pp. 3-8, 2014, doi: 10.1016/j.procir.2014.02.001.

[2] M. Hermann, T. Pentek, and B. Otto, "Design principles for industrie 4.0 scenarios," Proc. Annu. Hawaii Int. Conf. Syst. Sci., vol. 2016March, pp. 3928-3937, 2016, doi: 10.1109/HICSS.2016.488.

[3] M. A. Ghufron, "Revolusi industri 4.0: Tantangan, Peluang dan Solusi Bagi Dunia Pendidikan," Semin. Nas. dan Disk. Panel Multidisiplin Has. Penelit. dan Pengabdi. Kpd. Masy., pp. 332-337, 2018.

[4] R. Heinich, "Revolusi industri 4.0: Tantangan, Peluang dan Solusi Bagi Dunia Pendidikan," in Seminar Nasional Dan Diskusi Panel Multidisiplin Hasil Penelitian Dan Pengabdian Kepada Masyarakat, 2005, pp. 332-337.

[5] B. Trilling and C. Fadel, 21st-Century Skills: Learning for Life in Our Times. US: JosseyBass A Wiley Imprint, 2009.

[6] D. Retnosari and M. R. Wathani, "Sistem Informasi E-Learning Untuk Pengembangan," vol. 18, no. 2, pp. 191-200.

[7] D. Puyada, G. Ganefri, A. Ambiyar, R. E. Wulansari, and B. H. Hayadi, "Effectiveness of Interactive Instructional Media on Electrical Circuits," Int. J. Eng. Technol., vol. 7, pp. 220223, 2018.

[8] M. Wardaszko and B. Podgórski, "Mobile Learning Game Effectiveness in Cognitive Learning by Adults: A Comparative Study," Simul. Gaming, vol. 48, no. 4, pp. 435-454, 2017, doi: 10.1177/1046878117704350.

[9] D. Pernanda, M. A. Zaus, R. E. Wulansari, and S. Islami, "Effectiveness of instructional media 
based on interactive cd learning on basic network at vocational high school : improving student cognitive ability Effectiveness of instructional media based on interactive cd learning on basic network at vocational hig," Int. Conf. Educ. Soc. Sci. Technol., no. February, 2018, doi: 10.24036/XXXXX.

[10] S. Erol, A. Jäger, P. Hold, K. Ott, and W. Sihn, "Tangible Industry 4.0: a scenario-based approach to learning for the future of production," Procedia CIRP, vol. 54, pp. 1318, 2016, doi: 10.1016/j.procir.2016.03.162.

[11] A. S. Helianak and H. D. Surjono, "engembangan E-Learning Mata Pelajaran Teknologi Informasi Dan Komunikasi (Tik) Di Sma Negeri 3 Kupang," J. Inov. Teknol. Pendidik., vol. 1, no. 1, pp. 1-14, 2014.

[12] H. Pratama, "Pengembangan pembelajaran elearning berbasis moodle pada materi pedosfer kelas X Sekolah Menengah Atas," UNM, 2011.

[13] I. Wijaya and A. H. Lubis, "perancangan dan pembuatan elearning berbasis moodle pada mata pelajaran Keterampilan Komputer Dan Pengelolaan Informasi ( Kkpi ).," vol. 5, no. 1, pp. 61-70, 2018.

[14] P. A., Sains dan Teknologi (G. P. Utama (ed.9). 2009.

[15] K. Winatha and Redy, "Pengembangan EModul Interaktif Berbasis Proyek Matematika," vol. 4, no. 2, pp. 57-63, 2018.

[16] S. Thiagarajan, D. S. Semmel, and M. I. Semmel, Instructional Development for Training Teachers of Expectional Children. Minneapolis, Minnesota: Leadership Training Institute/Special Education, University of Minnesota., 1974.

[17] U. Usmeldi, "Pengembangan Modul Pembelajaran Fisika Berbasis Riset dengan Pendekatan Scientific untuk Meningkatkan Literasi Sains Peserta Didik," J. Penelit. Pengemb. Pendidik. Fis., vol. 2, no. 1, pp. 1-8, 2016, doi: 10.21009/1.02101.

[18] Z. C. A. Dalu and M. Rohman, "Pengembangan E-Learning Sebagai Media Pembelajaran Simulasi dan Komunikasi Digital bagi Siswa SMK," Jupiter, vol. 04, no. 1, pp. 25-33, 2019.

[19] Z. Zyainuri and E. Marpanaji, "Penerapan elearning moodle untuk pembelajran siswa yang melaksanakan prakerin," J. Pendidik. Vokasi, vol. 2, no. 3, pp. 410-426, 2013.

[20] M. Fausih and D. T, "Media Modul Elektronik di Sekolah Menengah Kejuruan.," J. UNESA, vol. 01, no. 01, pp. 1-9, 2015.

[21] A. S. Helianak and H. D. Surjono, "Pengembangan E-Learning Mata Pelajaran
Teknologi Informasi Dan Komunikasi (Tik) Di Sma Negeri 3 Kupang," J. Inov. Teknol. Pendidik., vol. 1, no. 1, pp. 1-14, 2014.

[22] W. W. Lestari, "Pengembangan E-Learning Dengan Schoology Sebagai Suplemen Pembelajaran Fisika Pada Materi Hukum Gravitasi Newton," Universitas Negeri Lampung, 2016.

\section{Biodata Penulis}

Wirda Yetti, merupakan mahasiswa pascasarjana program magister di program studi Pendidikan teknologi dan kejuruan, Fakultas Teknik Universitas Negeri Padang, dan sekarang juga merupakan seorang guru di SMK Negeri 1 Lubuksikaping.

Ahyanuardi, merupakan dosen di jurusan Teknik Elektro fakultas Teknik Universitas Negeri, beliau merupakan seorang doctor yang sudah banyak melakukan penelitian di bidang elektro dan juga Pendidikan. 